\title{
Sodium Titanates Formation by Roasting of Pellets or Powder Mixture of Soda Ash and Rossetta Region Ilmenite Ore Concentrate in Air
}

\author{
Inass Ashraf Nafeaa1, Amina F. Zekry'1, Mohamed Gamal Khalifa², Abd El-Fatah B. Farag1, \\ Naglaa A. El-Hussiny ${ }^{3}$, Khaled El Hossiny ${ }^{4}$, Mohamed El-Menshawi Hussein Shalabi ${ }^{3 *}$ \\ ${ }^{1}$ Faculty of Science, Helwan University, Greater Cairo, Egypt \\ ${ }^{2}$ El-Tabbin Metallurgical Institute, Cairo, Egypt \\ ${ }^{3}$ Central Metallurgical Research and Development Institute, Cairo, Egypt \\ ${ }^{4}$ Nuclear Materials Authority (NMA), Cairo, Egypt \\ Email: shalabimeh@hotmail.com
}

Received 1 April 2014; revised 2 May 2014; accepted 9 May 2014

Copyright (C) 2014 by authors and Scientific Research Publishing Inc.

This work is licensed under the Creative Commons Attribution International License (CC BY).

http://creativecommons.org/licenses/by/4.0/

\section{(c) (i) Open Access}

\section{Abstract}

Alkaline metals and hydrogen titanates are of great interest for possible applications. The qualities of soda ash and Rosetta ilmenite ore concentrate pellets were investigated. The kinetic formation of sodium titanate via roasting of soda ash and ilmenite pellets and powder was studied in the temperature range of $800^{\circ} \mathrm{C}$ to $900^{\circ} \mathrm{C}$.

Keywords

Soda Ash, Ilmenite Pellets, Roasting, Ilmenite, Sodium Titanate

\section{Introduction}

Titanium dioxide is the most widely used white pigment because of its high brightness and refractive index. Anatase, brookite, and rutile are the natural forms of titanium dioxide minerals. Of many titanates, only a few are important industrially, particularly those of iron and calcium. Ilmenite $\left(\mathrm{FeTiO}_{3}\right)$ is a heavy mineral of metal-

*Corresponding author.

How to cite this paper: Nafeaa, I.A., et al. (2014) Sodium Titanates Formation by Roasting of Pellets or Powder Mixture of Soda Ash and Rossetta Region Ilmenite Ore Concentrate in Air. Open Journal of Metal, 4, 20-30. 
lic to sub metallic luster, which is formed in igneous rocks [1].

Thavadkar and Jha [2] indicated that the worldwide $\mathrm{TiO}_{2}$ was extracted from natural ilmenite, rutile, and anatase minerals via the sulphate and chloride processes. The sulphate process generates large volumes of less toxic wastes, whereas the chloride process, including the ilmenite-chloride process of DuPont, yields much lower volume of wastes, which are highly toxic and hazardous. The treatment and disposal of such hazardous chloride wastes are both expensive and difficult in terms of long-term monitoring. Besides the waste management and disposal, there is also a shortage of high-grade titanium dioxide minerals in nature, which consequently yields much larger tonnages of sulphate and chloride wastes. The results of an alternative titaniferous mineral beneficiation process are based on soda ash roasting of minerals. Compared to the conventional processes for beneficiation of $\mathrm{TiO}_{2}$-ores, the alkali roasting of titaniferous offers has several advantages including the zero process wastes. In the soda ash roasting process, the formation of liquid phase is a common problem that results in product granulation, formation of rings on the kiln walls and lump formation. In this soda ash roasting process the mineral is mixed with sodium carbonate and heated above $1023 \mathrm{~K}$ in air. The oxidative roasting of ores yields several complex alkali compounds, some of which produce a liquid mixture above $1123 \mathrm{~K}$.

El-Tawil, et al. [3], carried out reductive roasting of ilmenite ore by carbon in the presence of sodium carbonate at $1000^{\circ} \mathrm{C}-1200^{\circ} \mathrm{C}$ for periods of up to $180 \mathrm{~min}$. They found that the additions of sodium carbonate of up to $30 \mathrm{wt} \%$ of the ore enhanced the reduction efficiency and the maximum metallization obtained at $1200^{\circ} \mathrm{C}$ was about $85 \%$, and the rest of the iron exists in the form of sodium-iron-titanates. The type of sodium compound formed in the final product depends on the roasting temperature. The reduction rate data under isothermal conditions were represented by a phase-boundary reaction model for conversions of up to $70 \mathrm{wt} \%$. The apparent activation energy obtained is about $67 \mathrm{~kJ} / \mathrm{mol}$. Magnetic separation of roasted products gave different magnetic fractions with different $\mathrm{Fe} / \mathrm{TiO}_{2}$ ratios (ranging from 2 - 3) as well as a non-magnetic fraction that was low in iron and suitable for titanium dioxide production.

Over the last 30 years, a number of titanium-based substances have been developed that serve as effective ion exchangers in chemical separations [4]. For example, monosodium titanate (is an inorganic sorbent material that exhibits high selectivity for strontium and actinide elements in the presence of strongly alkaline and high sodium containing salt solutions [5]), and second sodium nonatitanate (SNT) [6] are amorphous or poorly crystalline materials that are effective ion-exchange materials for the removal of strontium and actinides (e.g., Pu, Np, U) from highly alkaline nuclear waste solutions. A new family of peroxotitanate materials having the general formula of $\mathrm{HvNawTi}_{2} \mathrm{O}_{5} \cdot\left(\mathrm{xH}_{2} \mathrm{O}\right)\left[\mathrm{yHzO}_{2}\right]$, has been prepared recently that offers increased selectivity and faster removal kinetics [7] [8].

Both the sodium titanates and peroxotitanates have been shown to be effective for the removal of a wide range of metal ions from neutral and weakly acidic solutions [9]. These results suggest that these materials could prove useful in the treatment of industrial wastewaters and contaminated groundwaters [9] in nuclear fuel reprocessing [10], and in a number of medical applications [11]-[15].

Alkaline titanates have attracted increasing attention [16], particularly for the applications based on their high photocatalytic activity, such as fuel cell electrolytes, cation exchangers for the treatment of radioactive liquid waste [17]-[19] and many other applications [20] [21].

The standard method for the preparation of sodium titanate consists of the reaction of $\mathrm{TiO}_{2}$ with fused $\mathrm{Na}_{2} \mathrm{CO}_{3}$ at temperatures around $1000^{\circ} \mathrm{C}[22]$.

Morsi et al. [23] indicated that sintering of ilmenite ore in the presence of certain mole ratio of sodium oxide (2.5) with respect to titanium dioxide followed by roasting at $1000^{\circ} \mathrm{C}, 1100^{\circ} \mathrm{C}$ or $1200^{\circ} \mathrm{C}$ for 120,60 or $30 \mathrm{mi}-$ nutes respectively is feasible for complete titanium dioxide recovery. The formation of the higher titanates $\mathrm{Na}_{8} \mathrm{Ti}_{5} \mathrm{O}_{14}$ and $\mathrm{Na}_{6} \mathrm{Ti}_{2} \mathrm{O}_{7}$ during the sintering process favors the formation of the lower titanates such as $\mathrm{Na}_{2} \mathrm{TiO}_{4}$ during subsequent roasting process, which is easily soluble in dilute sulfuric acid. The contaminated soluble iron compound in the leaching can be easily separated by simple technique.

Lasheen [24] studied the process of soda ash roasting of titana slag product from Rosetta ilmenite, and reported that the optimum conditions used a $\mathrm{Na}_{2} \mathrm{CO}_{3} /$ slag ratio of $0.55: 1$ and roasting temperature $850^{\circ} \mathrm{C}$ for 0.5 hour duration period. In the present investigation, the kinetic reaction roasting of soda ash and ilmenite ore concentrate was evaluated.

This work aimed to study the kinetics of sodium titanate formation from roasting of local ilmenite with different amounts of soda ash in case of spherical pellets and powder. 


\section{Experimental Work}

\subsection{Materials}

\subsubsection{Ilmenite Ore}

A representative sample of Rosetta ilmenite concentrate was provided from the Nuclear Materials Authority (NMA) titanium project. The composition of Rosetta ilmenite ore concentrate contains about $43.6 \% \mathrm{TiO}_{2}, 27.5 \%$ $\mathrm{FeO}$ and $20.9 \% \mathrm{Fe}_{2} \mathrm{O}_{3}$. X-ray diffraction analysis of Rosetta ilmenite ore concentrate is shown in Figure 1, which indicated that the phases composing Rosetta ore concentrate mainly consist of ilmenite $\mathrm{Fe}_{2} \mathrm{TiO}_{3}$, Pseudorutile $\mathrm{Fe}_{2} \mathrm{Ti}_{3} \mathrm{O}_{9}$, hematite $\mathrm{Fe}_{2} \mathrm{O}_{3}$ and a minor quantity of rutile according to the work which present in literatures [25] [26].

\subsubsection{Soda Ash}

Sodium carbonate anhydrous (Soda ash, analar grade) was provided from ADWIC CO.

\subsection{Experimental Procedures}

\subsubsection{Preparation and Physical Properties of the Pellets}

The ilmenite concentrate was ground in a vibrating mill to a size less than 75 micrometers. The ground ilmenite concentrate powder was mixed with different percentages of soda ash and then $200 \mathrm{~g}$ of mixture was fed to the disc pelletizer (diameter $400 \mathrm{~mm}$, collar height $100 \mathrm{~mm}$ ) under the following condition: angle of inclination $52^{\circ}$, disc rotating speed $17 \mathrm{rpm}$ and residence time 10 - $30 \mathrm{~min}$. The predetermined amount of water (9\%) was sprayed onto the rolling bed of material in the disc pelletizer. At the end of the tests, a pellet sample was collected and screened to collect the (5 - $7 \mathrm{~mm}$ diameter) fraction. The produced green pellets were dried in air for three days, to ensure the evaporation of water used during the pelletization process.

The pellets were then subjected to drop number and crushing strength tests. The drop number indicates how often pellet can be dropped from a height of $46 \mathrm{~cm}$ before they show perceptible cracks or crumble. Ten pellets (5 - $7 \mathrm{~mm}$ ) were individually dropped onto a steel plate. The number of drops is determined for each pellet. The arithmetical average values of the crumbing behavior of the ten pellets yield the drop number. [27] [28] Ten pellets were compressed between parallel steel plates up to failure to determine the average crushing strength [27] [28].

\subsubsection{Roasting Process}

Roasting of the produced pellets was performed in a thermo balance apparatus shown in Figure 2 [28]. It consists of a vertical furnace, an electronic balance for monitoring the weight change of reacting sample and a temperature controller. The sample is placed in a nickel chrome crucible, which was suspended under the electronic balance by Ni-Cr wire. The furnace temperature was raised to the required temperature $700^{\circ} \mathrm{C}$ to $900^{\circ} \mathrm{C}$ and maintained constant to $\pm 5^{\circ} \mathrm{C}$. Then the samples were placed in hot zone.

Samples were continuously withdrawn from the furnace at specific times and put in a desiccator to determine the percentage of titanium oxide converted to sodium titanates.

The percentage of titanium oxide converted to sodium titanates was calculated according to the following equation:

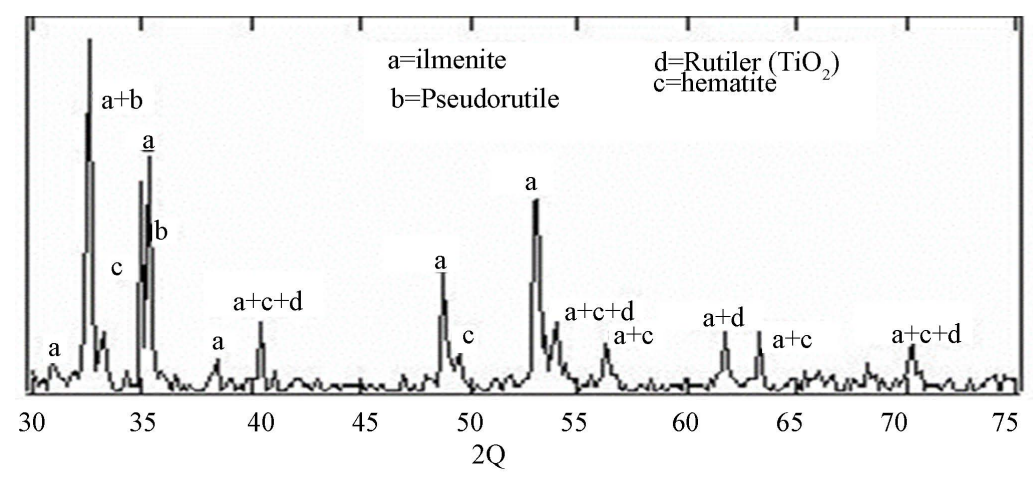

Figure 1. XRD analysis of Rosetta ilmenite ore concentrate. 


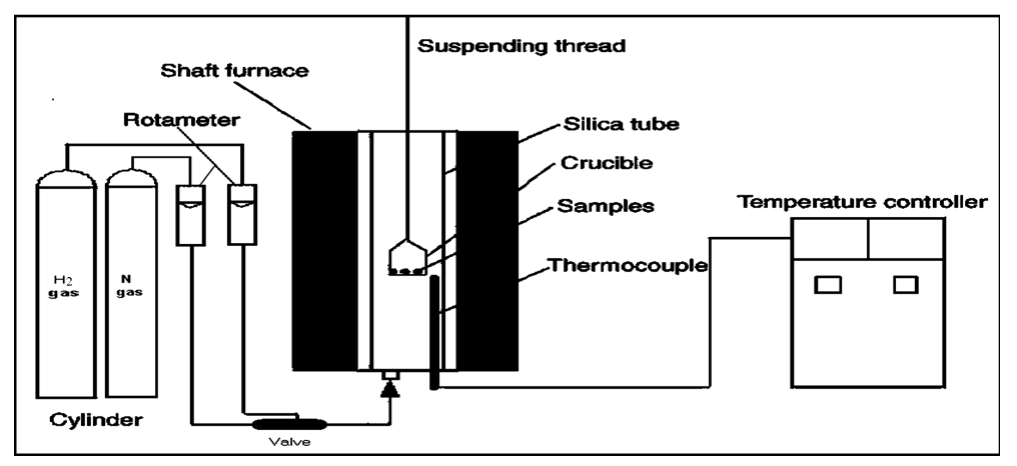

Figure 2. A schematic diagram of thermo balance apparatus.

Percentage of titanium oxide converted to sodium titanates $=\frac{W_{t} \times 100}{W_{0}}$

where:

$W_{0}$ : The initial mass of titanium oxide in the sample before roasting;

$W_{t}$ : Mass of titanium oxide converted to sodium titanates after roasting time (t).

\section{Results and Discussion}

\subsection{Effect of the Change of the Amount of Soda Ash Added on the Quality of the Pellets of Soda Ash and Ilmenite Mixture.}

In this experiment, ilmenite with different amount of soda ash were pelletized in disc pelletizer with $6 \%$ of water (inclination of disc pelletizer $=55^{\circ}$ and the produced pellets remained in the disc pelletizer $30 \mathrm{~min}$ ).

Figure 3 \& Figure 4 show the effect of the amount of soda ash added to the ilmenite on the drop number and crushing strength of the produced pellets. From these figures, it is clear that both drop number and crushing strength increased as the percentage of soda ash increased. From these figures, it is clear that as the percentage of soda ash increased both the drop damage resistance and crushing strength increased. This may be because increase of soda ash increases the compaction of pellets increased due to the finest of soda ash and subsequently the Vander Waals forces increased [29] [30].

\subsection{Effect of the Soda Ash Amount Added to Ilmenite on the Degree of Conversion of Titanium Oxide}

Figure 5 illustrates the effect of change in the percentage of soda ash added to ilmeniteore concentrate on the degree of conversion of titanium oxide to sodium titanates at $900^{\circ} \mathrm{C}$. From this figure, it is clear that the degree of conversion increased as the amount of soda ash increased. This may be attributed that the increase of soda ash leads to an increase the amount of sodium oxide than the amount of sodium oxide, which consumed in the side reaction such as the reaction with $\mathrm{Fe}_{2} \mathrm{O}_{3}, \mathrm{Cr}_{2} \mathrm{O}_{3}$, etc.

\subsection{Effect of Roasting Temperature on the Degree of Conversion of Titanium Oxide}

Experiments were performed in the temperature range $800^{\circ} \mathrm{C}$ to $900^{\circ} \mathrm{C}$. Plot of the degree of conversion of titanium oxide as a function of time is shown in Figure 6. It is clear that the degree of titanium oxide conversion to sodium titanate increased with increasing temperature. In addition, the degree of conversion to sodium titanates rates was faster in the first period and then decreased at the end of the period.

\subsection{Kinetics of Pellet Samples Roasted in Air}

Three dimensional spherical diffusion models were applied [31]

$$
\left[1-(1-\mathrm{R})^{1 / 3}\right]^{2}=\mathrm{kt}
$$




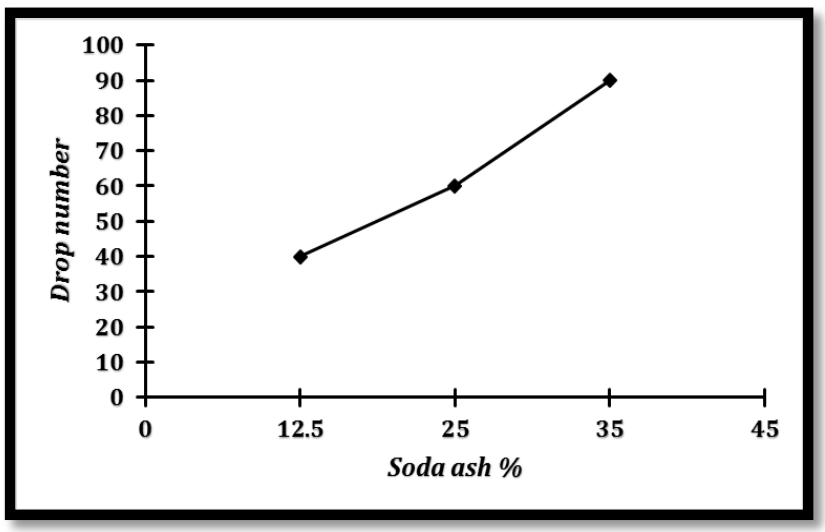

Figure 3. Relationship between amount changes of soda ash, and drop number for pellet samples.

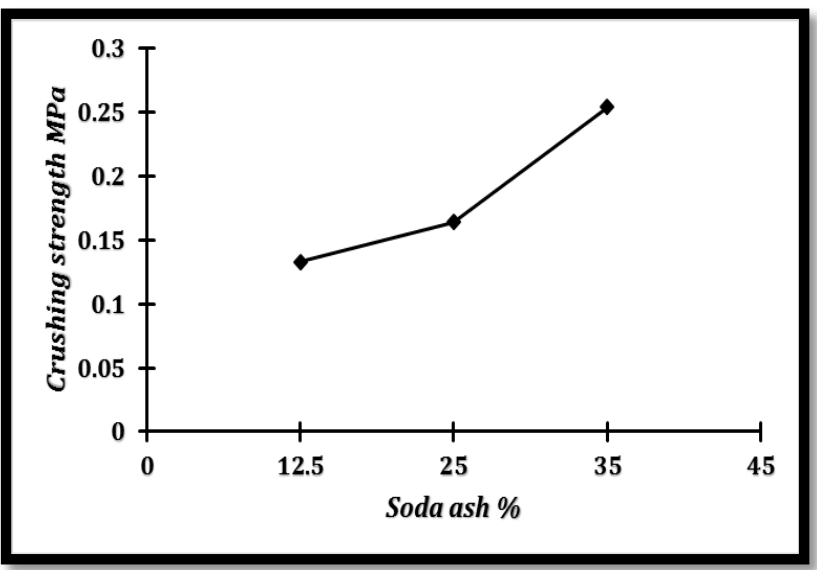

Figure 4. Relationship between the amount change of soda ash and crushing strength for pellet samples.

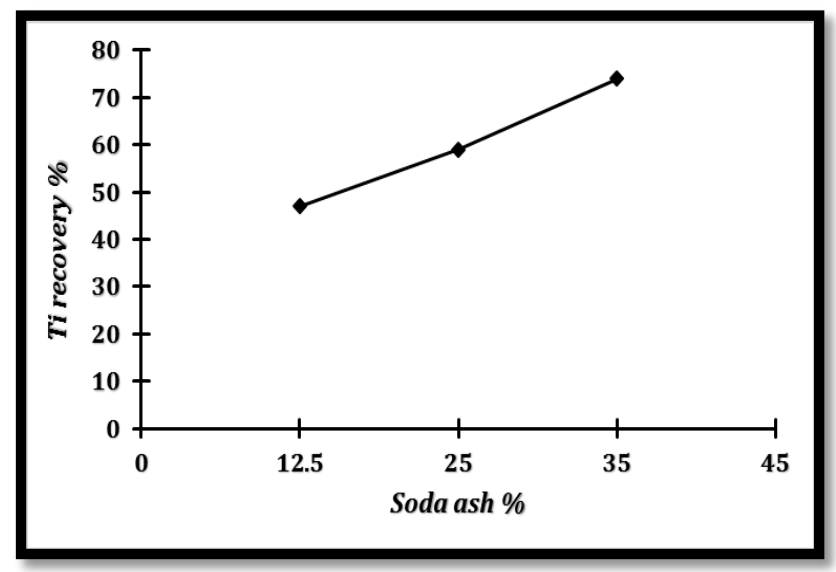

Figure 5. Relationship between the amount change of soda ash and degree of conversion of titanium oxide at $900^{\circ} \mathrm{C}$ for pellet samples.

where: $(\mathrm{R})$ the fractional conversion, $(\mathrm{t})$ the time of roasting min and $(\mathrm{k})$ the rate constant.

Figure 7 shows the relation between $\left[1-(1-\mathrm{R})^{1 / 3}\right]^{2}$ against time of conversion for different roasting temperatures, 


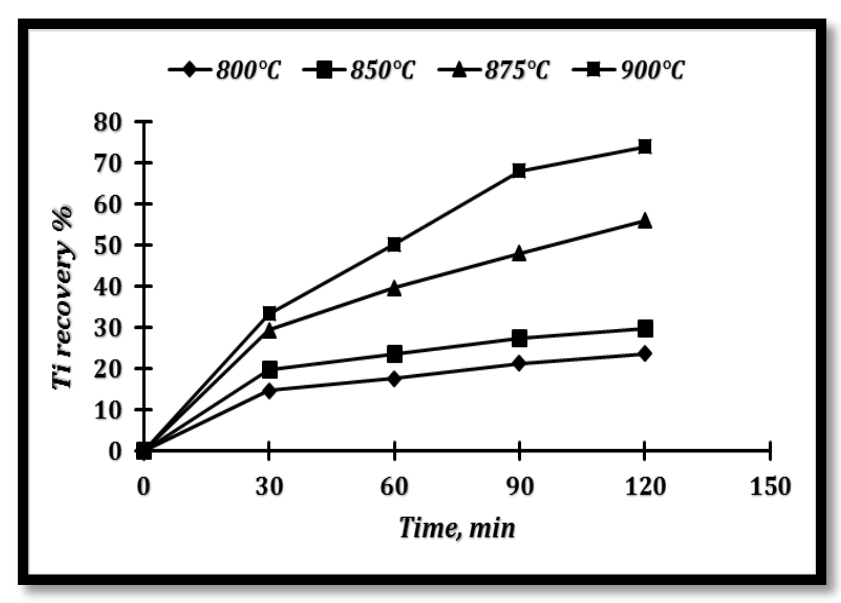

Figure 6. Effect of the roasting temperature change on the degree of conversion of titanium oxide for pellet samples.

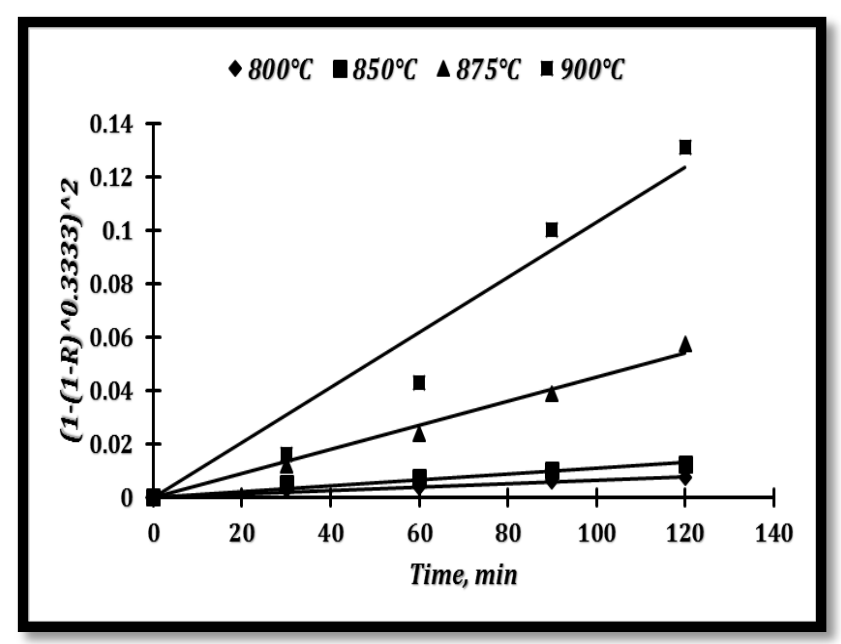

Figure 7. Relationship between $\left[1-(1-\mathrm{R})^{1 / 3}\right]^{2}$ and time of roasting at different temperatures.

from which, it is clear that the straight lines were observed.

The values of slopes of $\left[1-(1-\mathrm{R})^{1 / 3}\right]^{2}$ against time represent the reaction rate constant $\mathrm{k}$ at each temperature. Their logarithms were plotted in an Arrhenius type plot in Figure 8 as lnk against 1/T. A straight line could be fairly fitted through the points and the obtained slope $\mathrm{E} / \mathrm{R}=35.350 \mathrm{~K}$ corresponding to an activation energy equal to $294 \mathrm{~kJ} / \mathrm{mole}$.

\subsection{X-Ray Analysis of Some Pellet Samples Roasted in Air}

Figure 9 \& Figure 10 illustrate the X-ray analysis of the sample roasted at $800^{\circ} \mathrm{C}$ and $900^{\circ} \mathrm{C}$. From which, it is clear that the main phases of the sample roasted at $800^{\circ} \mathrm{C}$ in air are $\mathrm{NaTiO}_{2}, \mathrm{NaTi}_{2} \mathrm{O}_{4}, \mathrm{NaFeTiO}_{4}$ and $\mathrm{Na}_{2} \mathrm{Ti}_{3} \mathrm{O}_{7}$. The main phases of the sample roasted at $900^{\circ} \mathrm{C}$ in air are $\mathrm{NaTiO}_{2}, \mathrm{NaTi}_{2} \mathrm{O}_{4}, \mathrm{NaFeTiO}_{4}$ and $\mathrm{Na}_{2} \mathrm{Ti}_{3} \mathrm{O}_{7}$.

\subsection{Results of Ilmenite and Soda Ash Powder Samples Roasted in Air}

\subsubsection{Effect of Roasting Temperature on the Degree of Conversation of Titanium Oxide}

In this experiment powder mixture of ilmenite and soda ash (35\%) were roasted in air at temperature range $750^{\circ} \mathrm{C}$ to $900^{\circ} \mathrm{C}$. Figure 11 shows the results of this experiment from which, it is clear that as the temperature increased the degree of conversion increased this due to the same reasons explained before. 


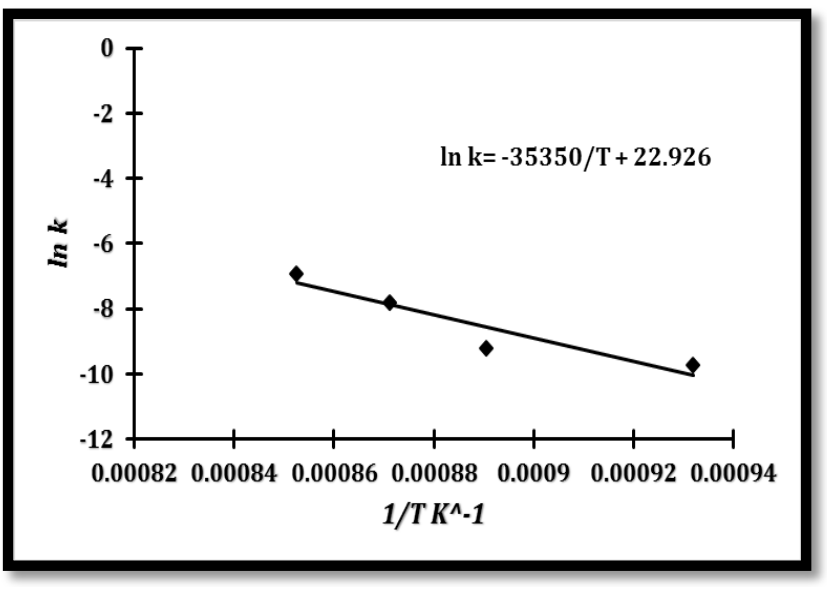

Figure 8. Relationship between $1 / \mathrm{T}$ and lnk (Arrhenius plot for roasting reaction).

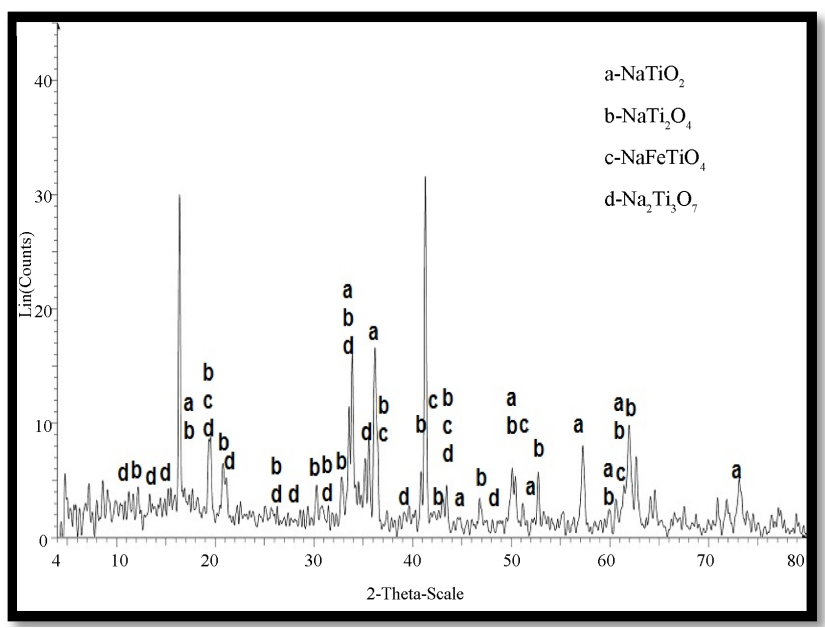

Figure 9. X-ray analysis of the pellet sample roasted at $800^{\circ} \mathrm{C}$ in air.

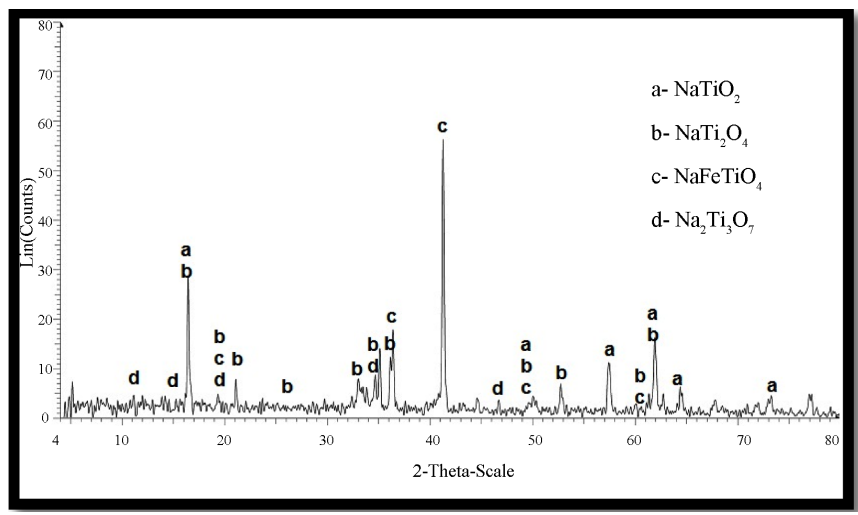

Figure 10. X-ray analysis of the pellet sample roasted at $900^{\circ} \mathrm{C}$ in air.

\subsubsection{Kinetics of Powder Samples Roasted in Air}

Three dimensional spherical diffusion models were applied [31] 


$$
\left[1-(1-\mathrm{R})^{1 / 3}\right]^{2}=\mathrm{kt}
$$

where: $(\mathrm{R})$ the fractional conversion, $(\mathrm{t})$ the time of roasting min. and (k) the rate constant. Figure 12 shows the relation between $\left[1-(1-\mathrm{R})^{1 / 3}\right]^{2}$ against time of conversion for different roasting temperatures. From which it is clear that the straight line observed.

Because of the fact that conversions at only three temperatures were obtained, it was thought more convenient not to perform an Arrhenius plot to calculate activation energy as the result would not be necessarily reliable.

\subsubsection{X-Ray Analysis of Some Powder Samples Roasted in Air}

Figure 13 \& Figure 14 illustrated the X-ray analysis of the sample roasted at $750^{\circ} \mathrm{C}$ and $900^{\circ} \mathrm{C}$. From which, it is clear that the main phases of the sample roasting at $750^{\circ} \mathrm{C}$ in air are $\mathrm{NaFeTiO}_{4}, \mathrm{NaTi}_{2} \mathrm{O}_{4}, \mathrm{Na}_{2} \mathrm{Ti}_{3} \mathrm{O}_{7}, \mathrm{NaFeO}$, $\mathrm{NaTiO}_{2}$ and $\mathrm{Na}_{8} \mathrm{Ti}_{5} \mathrm{O}_{14}$. The main phases of the sample roasted at $900^{\circ} \mathrm{C}$ in air are $\mathrm{NaFeTiO}_{4}, \mathrm{NaTi}_{2} \mathrm{O}_{4}, \mathrm{Na}_{2} \mathrm{Ti}_{3} \mathrm{O}_{7}$, $\mathrm{NaFeO}_{2}$ and $\mathrm{Na}_{8} \mathrm{Ti}_{5} \mathrm{O}_{14}$.

\section{Conclusions}

- Both drop number and crushing strength of the mixed pellets of ilmenite and (35\%) soda ash increased as the amount of soda ash increased, where the inclination of disc pelletizer and time of pelletization are kept constant.

- The degree of conversion increased as the amount of soda ash increased when roasting the mixed pellets of ilmenite and (35\%) soda ash in air at different time at constant temperature.

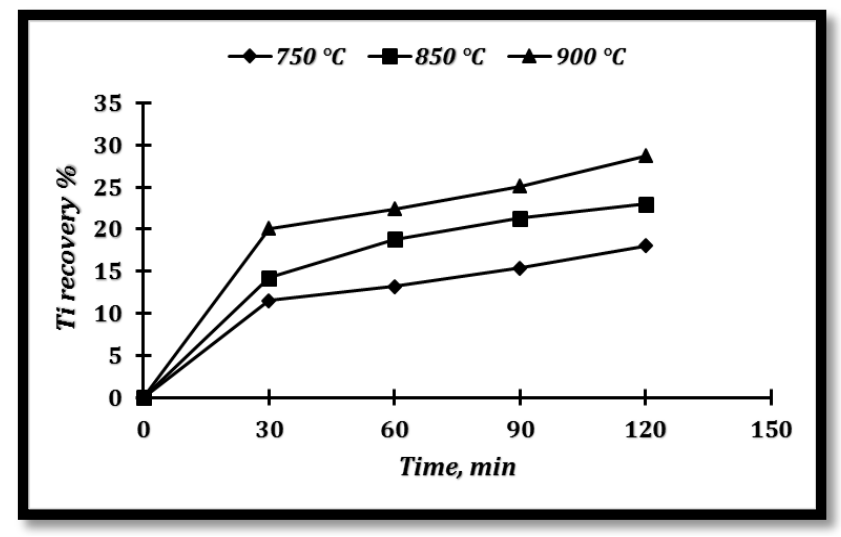

Figure 11. Effect of roasting temperature change on the degree of conversion of titanium oxide for powder samples.

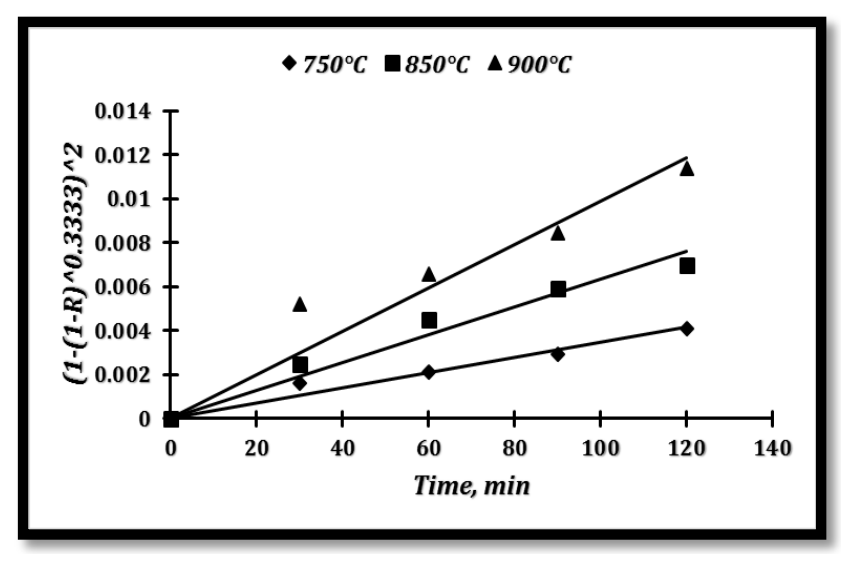

Figure 12. Relationship between $\left[1-(1-\mathrm{R})^{1 / 3}\right]^{2}$ and time of roasting at different temperatures. 


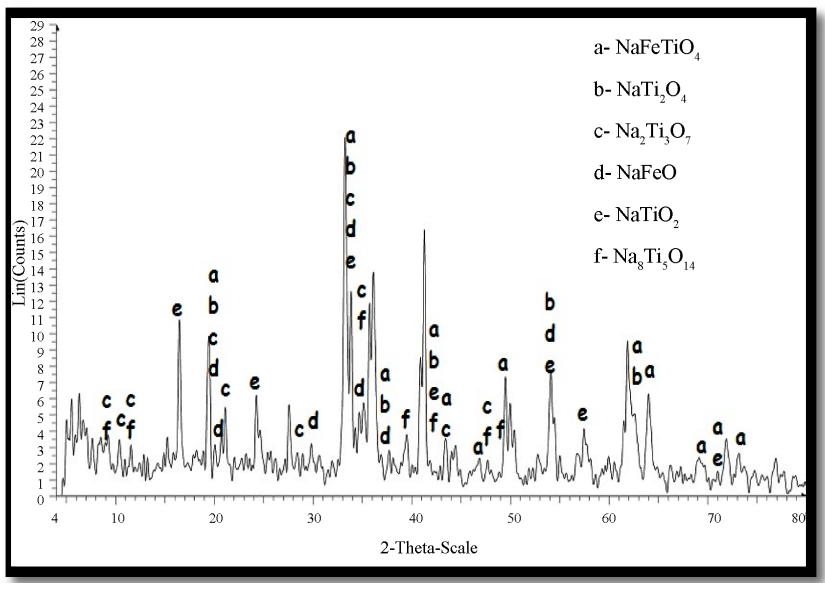

Figure 13. X-ray analysis of powder sample roasted at $750^{\circ} \mathrm{C}$ in air.

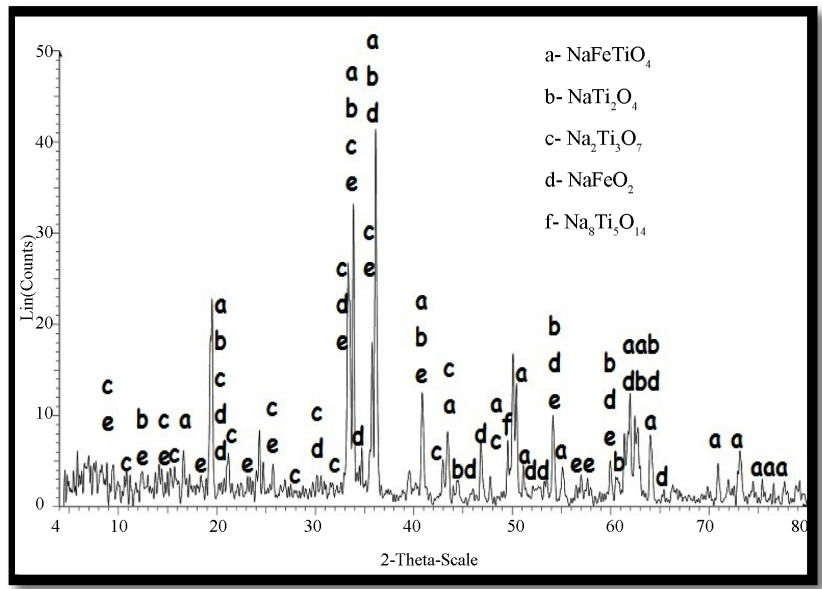

Figure 14. X-ray analysis of powder sample roasted at $900^{\circ} \mathrm{C}$ in air.

The degree of conversion of titanium oxide to sodium titanate increased with increasing the temperature of roasted pellets. In addition, it is clear that the recovery of sodium titanates rates was faster in the first period then decreased at the end of the period.

- Kinetics of roasted pellets ilmenite ore with (35\%) soda ash in air using three dimensional spherical diffusion model was described by Jander-Anorg equation

$$
\left[1-(1-\mathrm{R})^{1 / 3}\right]^{2}=\mathrm{kt}
$$

The results indicated that the activation energy was equal to $294 \mathrm{~kJ} / \mathrm{mole}$.

- X-ray analysis of pellet samples showed that the main phases of samples roasted at $800^{\circ} \mathrm{C}$ in air were $\mathrm{NaTiO}_{2}$, $\mathrm{NaTi}_{2} \mathrm{O}_{4}, \mathrm{NaFeTiO}_{4}$ and $\mathrm{Na}_{2} \mathrm{Ti}_{3} \mathrm{O}_{7}$, while the main phases of samples roasted at $900^{\circ} \mathrm{C}$ in air were $\mathrm{NaTiO}_{2}$, $\mathrm{NaTi}_{2} \mathrm{O}_{4}, \mathrm{NaFeTiO}_{4}$ and $\mathrm{Na}_{2} \mathrm{Ti}_{3} \mathrm{O}_{7}$.

- The degree of conversion of titanium oxide to sodium titanates increases with increasing roasting temperature in mixed powder samples of ilmenite with (35\%) soda ash.

- Kinetics of the roasted powder samples using three dimensional spherical diffusion model was described by Jander-Anorg equation

$$
\left[1-(1-\mathrm{R})^{1 / 3}\right]^{2}=\mathrm{kt}
$$


- X-ray analysis of powder samples showed that the main phases of samples roasted at $750^{\circ} \mathrm{C}$ in air were $\mathrm{NaFeTiO}_{4}, \mathrm{NaTi}_{2} \mathrm{O}_{4}, \mathrm{Na}_{2} \mathrm{Ti}_{3} \mathrm{O}_{7}, \mathrm{NaFeO}, \mathrm{NaTiO}_{2}$ and $\mathrm{Na}_{8} \mathrm{Ti}_{5} \mathrm{O}_{14}$, while the main phases of samples roasted at $900^{\circ} \mathrm{C}$ in air were $\mathrm{NaFeTiO}_{4}, \mathrm{NaTi}_{2} \mathrm{O}_{4}, \mathrm{Na}_{2} \mathrm{Ti}_{3} \mathrm{O}_{7}, \mathrm{NaFeO}_{2}, \mathrm{Fe}_{2} \mathrm{O}_{3}$ and $\mathrm{Na}_{8} \mathrm{Ti}_{5} \mathrm{O}_{14}$.

- It is evident that the roasting of pellets leads to more conversion than the roasting of the powder due to better contact between soda ash and ilmenite particles.

\section{References}

[1] Doan, P. (2003) Sustainable Development in the $\mathrm{TiO}_{2}$ Industry: Challenges and Opportunities. The $\mathrm{TiO}_{2}$ Intertech Conference, Miami, 3-5 February 2003.

[2] Tathavadkar, V. and Jha, A. (2004) The Effect of Molten Sodium Titanate and Carbonate Salt Mixture on the Alkali Roasting of Ilmenite and Rutile Minerals. VII International Conference on Molten Slags Fluxes and Salts, Cape Town, 25-28 January 2004, 255-261.

[3] El-Tawil, S.Z., Morsi, I.M., Yehia, A. and Francis, A.A. (1996) Alkali Reductive Roasting of Ilmenite Ore. Canadian Metallurgical Quarterly, 35, 31-37.

[4] Hobbs, D.T. (2011) Properties and Uses of Sodium Titanates and Peroxotitanates. Journal of the South Carolina Academy of Science, 9, 20-24.

[5] Lynch, R., Dosch, R., Kenna, B., Johnstone, J. and Nowak, E. (1976) The Sandia Solidification Process: A Broad Range Aqueous Solidification Method. Symposium on the Management of Radioactive Waste, Vienna, 22-26 March 1976, 360-372.

[6] Clearfield, A. and Lehto, J. (1988) Preparation, Structure, and Ion-Exchange Properties of $\mathrm{Na}_{4} \mathrm{Ti}_{9} \mathrm{O}_{20} \cdot \mathrm{XH}_{2} \mathrm{O}$. Journal of Solid State Chemistry, 73, 98-106. http://dx.doi.org/10.1016/0022-4596(88)90059-X

[7] Nyman, M.D. and Hobbs, D.T. (2006) A Family of Peroxo-Titanate Materials Tailored for Optimal Strontium and Actinide Sorption. Chemistry of Materials, 18, 6425-6435.

[8] Nyman, M.D. and Hobbs, D.T. (2009) Hydrogen Peroxide Modified Sodium Titanates with Improved Sorption Capabilities. US Patent 7494640B1.

[9] Elvington, M.C., Click, D.R. and Hobbs, D.T. (2010) Improved Strontium and Actinide Separations. Separation Science and Technology, 45, 66-72. http://dx.doi.org/10.1080/01496390903401820

[10] Hobbs, D.T., Clearfield, A. and Burns, J. (2010) Presentation at the 34th Actinide Separations Conference, Argonne, 18 May 2010.

[11] Hobbs, D.T., Messer, R.L.W., Lewis, J.B., Click, D.R., Lockwood, P.E. and Wataha, J.C. (2006) Adsorption of Biometals to Monosodium Titanate in Biological Environments. Journal of Biomedical Materials Research Part B: Applied Biomaterials, 78B, 296-301.

[12] Davis, R.R., Hobbs, D.T., Lockwood, P.E., Messer, R.L.W., Prices, R., Lewis, J. B. and Wataha, J.C. (2007) In Vitro Bi- ological Effects of Sodium Titanate Materials. Journal of Biomedical Materials Research Part B: Applied Biomaterials, 83, 505-511. http://dx.doi.org/10.1002/jbm.b.30823

[13] Wataha, J.C., Hobbs, D.T., Lockwood, P.E., Davis, R.R., Elvington, M.C., Lewis, J.B. and Messer, R.L.W. (2009) Peroxotitanates for Biodelivery of Metals. Journal of Biomedical Materials Research Part B: Applied Biomaterials, 91B, 489-496.

[14] Davis, R.R., Hobbs, D.T., Khashaba, R., Sehkar, P., Seta, F.N., Messer, R.L.W., Lewis, J.B. and Wataha, J.C. (2010) Titanate Particles as Agents to Deliver Gold Compounds to Fibroblasts and Monocytes. Journal of Biomedical Materials Research Part A, 93A, 864-769.

[15] Wataha, J.C., Hobbs, D.T., Wong, J.J., Dogan, S., Zhang, H., Chung, K.-H. and Elvington, M.C. (2010) Titanates Deliver Metal Ions to Monocytes. Journal of Materials Science: Materials in Medicine, 21, 1289-1295.

[16] Meng, X.D., Wang, D., Liu, J. and Zhang, S. (2004) Preparation and Characterization of Sodium Titanate Nanowires from Brookite Nano Crystallites. Materials Research Bulletin, 39, 2163-2170.

[17] Choy, J.H., Lee, H.C., Jung, H. and Huang, S.J. (2001) A Novel Synthetic Route to $\mathrm{TiO}_{2}$ Pillared Layered Titanate with Enhanced Photo Catalytic Activity. Journal of Materials Chemistry, 11, 22-32.

[18] Corcoran, D.J.D., Tunstall, D.P. and Irvine, J.T.S. (2000) Hydrogen Titanates as Potential Proton Conducting Fuel Cell Electrolytes. Solid State Ionics, 136-137, 297-303.

[19] El-Naggar, I.M., Mowafy, E.A., Ali, I.M. and Aly, H.F. (2002) Synthesis and Sorption Behavior of Some Radioactive Nuclides on Sodium Titanate as Cation Exchanger Adsorption. Adsorption, 8, 225-234.

[20] Ramirez-Salgado, J. and Fabry, P. (2002) Feasibility of Potentiometric Oxygen Gas Sensor Based on Perovskite and Sodium Titanate Measuring Electrode. Sensors and Actuators B Chemical, 82, 34. 
[21] Ramirez-Salgado, J., Djurado, E. and Fabry, P. (2004) Synthesis of sodium Titanate Composites by Sol-Gel Method for Use in Gas Potentiometric Sensors. Journal of the European Ceramic Society, 24, 2477-2483.

[22] Zarate, R.A., Fuentes, R.A.S. and Fuenzalida, V.M. (2006) Chemical Composition and Phase Identification of Sodium Titanate Nanostructures Grown from Titania by Hydrothermal Processing. LNLS Activity Report, Brazilian Synchrotron Light Laboratory.

[23] Morsi, I.M., Abdullah F.H.A., Mohamed O.A., Shalabi M.E.H. and El-Tawil S.Z. (1992) Processing of Ilmenite Ore by Sintering/Roasting Technique. 3rd Mining, Petroleum and Metallurgy Conference, Cairo, 2-4 February 1992.

[24] Lasheen, T.A. (2008) Soda Ash Roasting of Titana Slag Product from Rosetta Ilmenite. Hydrometallurgy, 93, $124-128$.

[25] El-Hussiny, N.A. and Shalabi M.E.H. (2012) Studying the Pelletization of Rosetta Ilmenite Concentrate with Coke Breeze Using Molasses and Reduction Kinetics of Produced Pellets at $800^{\circ} \mathrm{C}$ to $1150^{\circ} \mathrm{C}$. Science of Sintering, $\mathbf{4 4}$, 113-126.

[26] El-Gawad, H.H.A., El-Hussiny, N.A., Wassef, M.A., Khalifa, M.G., Soliman, A.A.A. and Shalabi, M.E.H. (2012) Reducibility Study of Egyptian Ilmenite Ore Briquettes and Powder with Coke Breeze at $800^{\circ} \mathrm{C}-1100^{\circ} \mathrm{C}$. Indian Chemical Engineer, 54, 83-94.

[27] Mayer, K. (1980) Pelletization of Iron Ores. Springer-Verlag, Berlin. Heidelberg.

[28] El-Hussiny, N.A. and Shalabi, M.E.H. (2011) A Self-Reduced Intermediate Product from Iron and Steel Plates Waste Materials Using a Briquetting Process. Powder Technology, 205, 217-223.

[29] Mangena, S.J. and Du Cann, V.M. (2007) Binder Less Briquetting of Some Selected South African Prim Coking, Blend Coking and Weathered Bituminous Coals and the Effect of Coal Properties on Binder Less Briquetting. International Journal of Coal Geology, 71, 303-312.

[30] Mohamed, F.M., Ahmed, Y.M.Z. and Shalabi, M.E.H. (2004) Briquetting of Waste Manganese Ore Sinter Fine Using Different Binding Materials, Environmental Issues and Waste Management in Energy and Mineral Production SWEMP, 567-573.

[31] Jander, W. and Anorg, Z. (1927) Kinetic Model for Solid-State Reactions. Zeitschrift für Anorganische und Allgemeine Chemie, 163, 1-30. 